\title{
Los revocos de Medina Azahara. Parte I: Caracterización del material y procesos de alteración
}

\author{
Rendering mortars in Medina Azahara. Part. I: Material \\ characterization and alteration process
}

Fecha de recepción: 21-XI-96

Fecha de aceptación: 13-XII-96
M.T. BLANCO-VARELA, F. PUERT AS y A. PALOMo Instituto Eduardo Torroja de Ciencias de la Construcción (CSIC)

ESPAÑA

\section{RESUMEN}

En este trabajo se analizan y caracterizan los revocos que, todavia hoy, permanecen sobre algunos paramentos de los muros de la ciudad de Medina Azahara, expuestos a la intemperie. También se caracterizan algunos de los morteros de reparación aplicados en las distintas restauraciones de los revocos.

Los revocos están formados por tres clase de morteros, atendiendo a la composición de su ligante: de cal, de yeso y bastardos de cal y yeso. Los morteros de reparación que se han utilizado son de cal, a excepción del utilizado en la restauración de Félix Hernández (década de 1950), en una de las salas, que es de cemento portland.

La colonización biológica es la principal causa de deterioro de los morteros de cal, en tanto que la solubilización por las aguas de lluvia lo es en los morteros que contienen yeso.

\section{SUMMARY}

Rendering mortars, which are still exposed to the open air on some of the walls of Medina Azahara, are studied and characterized in this work. Some repairing mortars used in different previous restorations are also characterized.

Those rendering mortars are of different make considering the composition of their binder: lime, gypsum and mixed limei gypsum. Repairing mortars used in previous interventions are made of lime, excepting for a portland cement used by liélix Hernandez in the restoration of one of the rooms back in the 50 's.

Biological colonization is the main cause of decay in lime mortars, while in mortars made of gypsum, decay is a result of the solubilizating action of rain water.

\section{INTRODUCCIÓN}

Medina Azahara está situada en las colinas más bajas de la Sierra de Córdoba, al noroeste de la ciudad. Construida entre los años 929 y 944 por Abderramán III, a pocos kilómetros de la ciudad califal, ocupa una extensión de 120 hectáreas (1).

\section{INTRODUCTION}

Medina Azahara is located on top of one of the lowest hills of the Cordoban Sierra, at a short distance northwest of the Caliph 's city of Cordoba. It was built between 929 and 944 by Abderraman III, and fills a 120 hectare ground surface (1). 
La ciudad construida sobre tres grandes terrazas escalonadas, estaba toda ella doblemente amurallada, excepto por su lado norte donde la muralla era sólo una, defendida por torres.

Su excavación comienza en 1910, en la zona del palacio vivienda del Califa y el Salón Occidental y prosigue, de modo intermitente, a lo largo del siglo. Simultáneamente, a partir de los años 30 se emprenden obras de reconstrucción y restauración, coronando con morteros los muros excavados, con el fin de protegerlos frente al agua de lluvia.

Los muros están construidos con sillares de piedra arenisca y algunos de sus paramentos conservan restos de revocos y enlucidos, en ocasiones policromados. En algunas albercas, e incluso en suelos, se conservan también restos de los morteros de recubrimiento (2).

Los objetivos planteados en este trabajo fueron:

a) Caracterizar diversos revocos, tomados del conjunto arqueológico de Medina Azahara.

b) Caracterización de diversos morteros de reparación, utilizados en distintas intervenciones efectuadas sobre los revocos del conjunto arqueológico de Medina Azahara.

c) Determinar las causas de deterioro de los mencionados revocos.

\section{METODOLOGÍA DE ANÁLISIS DE LOS MATERIALES}

Se tomaron muestras de revocos y morteros de reparación en cinco zonas o salas del Conjunto Arqueológico.

Todas las muestras fueron examinadas a la lupa; destacándose las diferencias observadas en los distintos revocos, relativas a:

1) Naturaleza y tamaño de los áridos

2) Textura y uniformidad del ligante

3) Presencia de fisuras

4) Desarrollo y disposición de crecimientos biológicos

Con el objeto de caracterizar dichos materiales, así como de determinar los productos de alteración presentes, se procedió con la metodología que se describe a continuación.

Una fracción de cada muestra fue sometida a un proceso de molienda completa, hasta que el tamaño de las partículas era inferior a $88 \mu \mathrm{m}$.
The city is built on three huge stepped terraces. It was once completely surrounded with two rows of walls, excepting for the North side that had a single row reinforced with towers.

Excavations started in 1910, by the palace area, Caliph's habitat, and Occidental Room and were carried on at intervals through the whole century, although restoration and reconstruction works did not start until the 30 's. Both have been developed simultaneously, first covering with mortar the top of the excavated walls in order to protect them against the rain.

The walls have been built with sandstone ashlar and some of the faces still hold remainings of stuccos and sometimes polychromic plasterings. Also in some of the reservoirs and even on the floors some covering mortars are still preserved (2).

The goals for this work were :

a) To characterize the different rendering mortars of the Medina Azahara archeological site.

b) To characterize the repairing mortars used in the different actions undertaken on the stuccos at Medina Azahara archelological site.

c) To determine phenomena causing decay in such stuccos

\section{MATERIALS ANALYSIS METHODOLOGY}

Samples of stuccos and repairing mortars were taken from five areas or rooms of the Archeological site.

All samples were examined through a stereo microscope, and the particulars observed in all rederingsmortars/ stuccos were related to :

1) Nature and size of aggregates

2) Texture and uniformity of the binder

3) Presence of cracks

4) Localization and development of biological growths

In order to characterize such materials and to determine the alteration substances, the following methodology was developed:

A fraction of each sample was submitted to a complete grinding process until reaching a particle size lesser than $88 \mu \mathrm{m}$. 
Sobre las muestras molidas se realizaron los siguientes ensayos:

*Análisis mineralógico por Difracción de Rayos X (DRX) y/o espectroscopía IR.

*Determinación de su solubilidad en agua y en disolución de ácido $\mathrm{HCl}$ al $20 \%$ (vol.) y de $\mathrm{Na}_{2} \mathrm{CO}_{3}$ al $5 \%$ (en peso).

\section{RESULTADOS}

\section{Sala 1. Vivienda de Yafar}

En esta Sala, existen restos de paramentos revocados en un estado de conservación muy deficiente, algunos de los cuales conservan restos de policromía.

Estos revocos fueron intervenidos en 1986 y sus bordes están sellados con un mortero de reparación. Este mortero está, en ocasiones, algo despegado del revoco $y$, a veces, también de la piedra base del paramento.

En el paramento seleccionado para su estudio en esta Sala, existen restos de revocos a tres alturas. En las dos superiores, dichos revocos carecen de policromía y, en la inferior, quedan restos de policromía (roja, e incluso de una línea blanca). Las muestras, en número total de nueve, se tomaron a las tres alturas mencionadas.

En la Tabla I se dan los resultados del análisis por DRX y/o espectroscopía IR de las nueve muestras tomadas.

En la Tabla II se da la solubilidad en agua y/o medio ácido ( $\mathrm{HCl}$ al $20 \%$ ), de las muestras objeto de este estudio.

La muestra tomada en el revoco situado a la altura superior (MA-1) es un mortero de yeso, siendo el árido arena cuarzosa y cerámica molida. La relación árido/ligante es de 1/4. Su superficie está agrietada y, a través de la lupa, se ven los áridos separados de la matriz cementante, lo que indica procesos de disolución.

Sobre la superficie hay, en ocasiones, depósitos (MA-2), a modo de costras, que son de yeso, si bien contienen algo de nitrato.

La solubilidad del yeso en agua es muy superior a la que el cuarzo ó el material cerámico pueden presentar. Dicha solubilidad justifica tanto la morfología de la superficie como la precipitación superficial de costras de yeso.
On the grinded samples the following tests were carried out:

*Mineralogical analysis by XRD and/or IR spectroscopy.

*Solubility in water and in $\mathrm{HCl}$ acid solution at $20 \%$ (vol.) and in $\mathrm{Na}_{2} \mathrm{CO}_{3}$ at $5 \%$ (wt.).

\section{RESULTS}

\section{Room 1. Yafar's House}

In this Room, the surface of the walls still hold some pieces of stucco heavily decayed, yet, in some of them remainings of polychromy can be seen.

An intervention was undertaken in 1986 and their edges are now sealed with repairing mortar. Some of this repairing mortar is slightly detached from the rendering mortar and sometimes even this one is detached from the stone.

The wall surface selected for study has remainings of stucco at three levels. The two higher ones does not have any polychromy; in the lower one there are some traces of polychromy (red with a white stripe). Samples, a total of nine, were taken at the three mentioned levels.

In Table I the XRD results and/or IR spectroscopy analyses of the samples are given.

Samples solubility in water and/or in acid solution ( $\mathrm{HCl}$ at 20\%) is given in Table II.

The sample taken off from the higher level $(M A-1)$ is a gypsum mortar made with quartzose sand and crushed ceramics as aggregate. The agregate/binder ratio is 1/4. Its surface is cracked and through the stereo microscope aggregates split off the cementing matrix can be seen, which indicates a dissolution process.

On the surface there are occasional gypsum deposits $(M A-2)$ hardened into crusts, although with some nitrate content.

The gypsum solubility in water is much higher than quartz or any ceramic material. Such solubility justifies both the morphology of the surface and the superficial precipitation of the gypsum crusts. 
TABLA I (TABLE I)

Composición mineralógica de las muestras tomadas en la Sala 1.Intensidades relativas (\%), de las reflexiones de DRX y de las bandas de absorción IR características de las fases

(Mineralogical composition of the samples taken in Room 1. Relative intensity (\%), of XRD reflection patterns and of IR absortion bands, characteristic of the phases)

\begin{tabular}{|c|c|c|c|c|c|c|}
\hline DRX & $\begin{array}{c}\text { CUARZO } \\
\text { (QUARTZ) } \\
2 \theta=26,6\end{array}$ & $\begin{array}{c}\text { YESO } \\
\text { (GYPSUM) } \\
2 \Theta=11,7\end{array}$ & $\begin{array}{l}\text { CALCITA } \\
\text { (CALCITE) } \\
2 \Theta=29,4\end{array}$ & $\begin{array}{l}\text { NITRATO } \\
\text { (NITRATE) }\end{array}$ & $\begin{array}{c}\text { FELDESP } \\
\text { (FELDSPAR) } \\
2 \Theta=27,5\end{array}$ & $\begin{array}{c}\text { OTROS } \\
(O T H E R) \\
2 \Theta=30,9\end{array}$ \\
\hline MA-1 & 7 & 100 & 3 & -.. & 0,5 & --- \\
\hline MA-3 & 100 & 1 & 55,7 & --- & 16 & 38 \\
\hline $\begin{array}{c}\text { MA-4 } \\
\text { TOTAL } \\
\text { (TOTAL) }\end{array}$ & 5 & 100 & 6 & --- & --- & --- \\
\hline MA-5 & 100 & --- & 37 & --- & 16 & 12 \\
\hline MA- 6 & 100 & 1 & 43 & --- & 19 & 8 \\
\hline MA-7 & 14 & 41 & 100 & -.. & 19 & --- \\
\hline MA-8 & 13 & 100 & 77 & $\ldots$ & 1 & $\ldots$ \\
\hline MA-9 & 3 & 48 & 100 & $\ldots$ & -.. & -.. \\
\hline \multicolumn{7}{|c|}{$\mathbb{I R}$} \\
\hline MA-2 & --- & $x x x$ & --- & $x$ & ... & -.. \\
\hline $\begin{array}{l}\text { MA-4 } \\
\text { BORDE } \\
\text { (EDGE) }\end{array}$ & $x x x$ & $x x$ & $x x x$ & 0 & $-\cdot$ & -.- \\
\hline
\end{tabular}

$x x x$ muy abundante, $x x$ abundante, $x$ poco, o trazas

(xxx very abundant, $x x$ less abundant, $x$ scarce, $o$ small quantities)

TABLA II (TABLE II)

Solubilidad de las muestras en $\mathrm{H}_{2} \mathrm{O}$ y medios ácidos (\% en peso)

(Solubility of the samples in $\mathrm{H}_{2} \mathrm{O}$ and acid solution (Weight \%))

\begin{tabular}{|c|c|c|}
\hline & $\mathrm{H}_{2} \mathrm{O}$ & $\mathrm{HCl}(20 \%)+\mathrm{Na}_{2} \mathrm{CO}_{3}$ \\
\hline MA-1 & 77,4 & $\ldots$ \\
\hline MA-3 & -- & 54 \\
\hline MA-4 & 73 & $\cdots$ \\
\hline MA-6 & -- & 46 \\
\hline MA-7 & 36 & $\ldots$ \\
\hline MA-8 & 30,5 & 89 \\
\hline MA-9 & 17 & 90 \\
\hline
\end{tabular}


El mortero de reparación con el que se ha pretendido proteger y sellar los bordes del revoco (MA-3), es de cal con árido, fundamentalmente silícico. La relación árido/ligante es $2 / 1$. El análisis de la fracción soluble en ácido clorhídrico de este mortero confirma la total ausencia de cemento portland en su dosificación.

La superficie externa del mortero de reparación MA-3, presenta colonización biológica.

En la zona intermedia se han tomado tres muestras MA-4, MA-5 y MA-6.

La muestra MA-4 es la más externa, está situada sobre la MA-5 y MA-6, que están en contacto con la piedra. Dicha muestra está constituida esencialmente por yeso (73\%) y en su parte externa presenta intensos surcos verticales de solubilización. En uno de sus bordes contiene un mortero de sellado de unos $7 \mathrm{~mm}$ de espesor, que es un mortero de cal con árido silíceo, similar al anteriormente descrito (MA-3). El mortero de borde, en su parte externa, tiene depósitos de yeso y en su parte interna también, sin embargo, en masa, contiene, sobre todo, $\mathrm{CaCO}_{3}$.

Las muestras MA-5 y MA-6 son muy similares y se trata de morteros de cal con relación árido/ligante, 1/1. Ambas muestras son enormemente heterogéneas, conteniendo trozos cerámicos en su masa de cerca de $1 \mathrm{~cm}$ de longitud. $\mathrm{El}$ árido de menor granulometría es silíceo, conteniendo esencialmente cuarzo y feldespatos como especies mineralógicas. La cantidad de árido calizo es pequeña.

En la zona inferior se tomaron también tres muestras MA-7, MA-8 y MA-9.

Las muestras MA-7 Y 8 tienen restos de policromía roja. Su aspecto está muy deteriorado. En cuanto a su naturaleza, las dos muestras son morteros bastardos, constituidos por $30-35 \%$ de yeso, $55-60 \%$ de $\mathrm{CaCO}_{3}$ y en torno al $9 \%$ de árido.

La muestra MA-9, situada bajo MA-7 contiene yeso y calcita como fases mayoritarias, en proporción del $17 \%$ y $73 \%$ en peso respectivamente, siendo el contenido en árido en torno al $10 \%$.

\section{Sala 2. Vivienda de Yafar}

Como en la Sala 1, los revocos situados a una mayor altura carecen de policromía en tanto que los más próximos al suelo conservan restos de la misma.

Los revocos de esta Sala fueron intervenidos en 1988. Así, parte de ellos tienen su borde protegido por un mortero de reparación, aunque en algunas zonas, si
The repairing mortar used to protect and seal the edges of the stucco (rendering mortars) (MA-3), is made of lime and basically siliceous aggregate. The aggregate/binder ratio is $2 / 1$. The analysis of the soluble fraction of this mortar in hydrochloric acid ascertain the total absence of portland cement in the dosage.

The external surface of the repairing mortar MA-3 shows biological colonization.

In the intermediate zone three samples, $M A-4, M A-5$ and $M A-6$, were taken.

Sample MA-4 is the most external one. It was over $M A-5$ and $M A-6$, both in contact with the stone. MA-4 is mostly made of gypsum (73\%) and deep grooves can be seen in its external side indicating solubilization. One of the edges is covered with a sealing mortar $7 \mathrm{~mm}$ thick made with lime and a siliceous aggregate very similar to the one previously described (MA-3). The edging mortar has gypsum deposits in both its external and internal face. However, in the inner part it has mostly $\mathrm{CaCO}_{3}$.

Samples MA-5 and MA-6 are very similar. They are lime mortars with an aggregate/binder ratio of $1 / 1$. Both samples content is very heterogeneous, since their mass hold ceramic chunks close to $1 \mathrm{~cm}$ long. The aggregate with lesser granulometry is siliceous with a high content of quartz and feldspar as mineralogical species. The amount of limestone aggregate is small.

Also three samples: $M A-7, M A-8$ and MA-9 were taken from the lower zone.

MA-7 and MA-8 show some remainings of red polychromy. Their aspect is of deep deterioration. As for their nature, both samples are constituted of 30-35\% gypsum, 55-60\% $\mathrm{CaCO}$ and around $9 \%$ aggregate.

Sample MA-9, located under MA-7 contains gypsum and calcite as majoriry phases in a proportion of $17 \%$ and $73 \%$ in weight respectively; the content of aggregate is approximately $10 \%$

\section{Room 2. Yafar's House}

Same as in Room 1, rendering mortars located at the higher level lack of polychromy but those closer to the floor still keep some.

In 1988 the rendering mortars of this Room went through an intervention, and now most of them have their edges protected with a repairing mortar although 
existió dicho mortero, ya no quedan restos del mismo. No se tiene constancia de la ejecución de otro tipo de reparación, o de que se haya aplicado algún tipo de consolidante.

En esta sala se tomaron muestras a dos alturas. Las muestras MA-11, 12, 13 y 14, corresponden a la altura superior y la MA-15 y 16, a la inferior (Ver Figura 1).

En la Tabla III se dan los resultados obtenidos del estudio a través de difracción de rayos $X$. En la Tabla IV se dan algunos datos de solubilidad de las muestras en $\mathrm{H}_{2} \mathrm{O}$ y en medio ácido ( $\left.\mathrm{HCl} 1: 5\right)$.

La muestra MA-11 es un revoco de yeso ( $80 \%$ en peso), casi carente de árido (5\%). El árido es, sobre todo, cerámico. La superficie externa de esta muestra presenta profundos surcos que se desarrollan en sentido vertical y que son señales evidentes de solubilizaciones diferenciales.

Las muestras MA-12 y 13 son morteros de cal, siendo su árido arena cuarzosa y feldespatos. La relación árido/ligante es de 3/1.

Finalmente, la muestra MA-14 es una dura costra de yeso, procedente de la disolución interna y posterior cristalización en superficie.

En la muestra MA-15, tomada de la zona inferior del estucado, se pueden distinguir dos partes: una, más superficial, que contiene restos de capa pictórica y otra, más interna. some stretches, if once mortar existed, nowadays are bare. There is no evidence of any other kind of repair, or any other kind of strengthner being applied.

In this room samples were taken at two different heights. Samples $M A-11,12,13$ and 14 correspond to the higher level and samples MA-15 and 16 to the lower level( See Figure 1).

In Table III, results obtained through XRD are given, and in Table IV some data about samples solubility in $\mathrm{H}_{2} \mathrm{O}$ and in acid solution ( $\mathrm{HCl} 1: 5)$.

Sample MA-11 is a gypsum mortar (80\% of its weight) with a very low proportion of aggregate (5\%), which is mostly ceramic. The external surface of the sample is crossed with vertical grooves which evidences differencial solubilizations.

Samples MA-12 and 13 are lime mortars whose aggregate is quartz sand and feldspar. The aggregate/binder ratio is $3: 1$.

Finally, sample MA-14 is a hard crust of gypsum resulting from internal dissolution and further crystallization of the surface.

In sample MA-15 taken from the lower area of the stucco, two zones can be differentiated: one internal, the other superficial containing rests of a depicted coat.

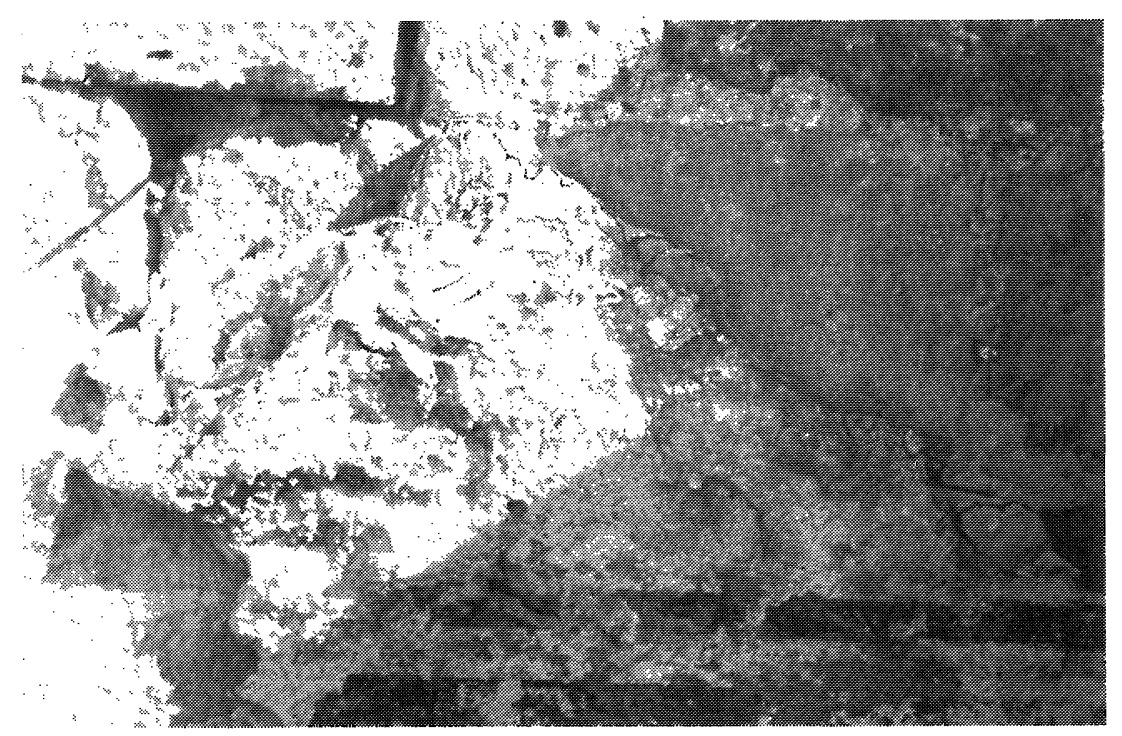

Fig. 1.- Sala 2. Vivienda de Yafar. Recubrimientos con signos evidentes de disolución. Los bordes están sellados por un mortero de cal. En la parte baja se observan restos de policromía.

Fig. 1.- Room 2. Yafar's House. Renderings with visible signs of desintegration/dissolution. The edges are sealed with a lime mortar. In the lower part rests of polychromy can be seen. 
TABLA III (TABLE III)

Composición mineralógica de las muestras tomadas en la Sala 2. Intensidades

relativas de las reflexiones características de las fases

(Mineralogical composition of samples taken in Room 2. Relative intensities of the characteristic diffraction lines of the phases)

\begin{tabular}{|c|c|c|c|c|c|}
\hline & $\begin{array}{l}\text { CUARZO } \\
\text { (QUARTZ) } \\
2 \Theta=11,7^{\circ}\end{array}$ & $\begin{array}{c}\text { YESO } \\
\text { (GYPSUM) } \\
2 \theta=11,7^{\circ}\end{array}$ & $\begin{array}{l}\text { CALCITA } \\
\text { (CALCITE) } \\
20=29,4^{\circ}\end{array}$ & $\begin{array}{c}\text { FELDESPATO } \\
\text { (FELDSPAR) } \\
2 \Theta=27,5^{\circ}\end{array}$ & $\begin{array}{c}\text { OTROS } \\
\text { (OTHER) } \\
20=30,9\end{array}$ \\
\hline $\mathrm{MA}-11$ & 2 & 100 & 7 & --- & $\ldots$ \\
\hline MA-12 & 100 & --- & 39 & 12 & 21 \\
\hline $\mathrm{MA}-13$ & 100 & --- & 44 & 16 & 26 \\
\hline $\mathrm{MA}-14$ & 2 & 100 & 2 & --- & -- \\
\hline $\begin{array}{c}\text { MA-15 } \\
\text { SUPERF. } \\
\text { (SURFACE) }\end{array}$ & 24 & 100 & 88 & --- & -- \\
\hline $\begin{array}{c}\text { MA-15 } \\
\text { MORTERO } \\
\text { (MORTAR) }\end{array}$ & 18 & --- & 100 & 3 & $\cdots$ \\
\hline MA-16 & 5 & 18 & 100 & --- & $\ldots$ \\
\hline
\end{tabular}

TABLA IV (TABLE IV)

Solubilidad de las muestras en $\mathrm{H}_{2} \mathrm{O}$ y medios ácidos (\% en peso)

(Solubility of the samples in $\mathrm{H}_{2} \mathrm{O}$ and acid solution (Weight \%))

\begin{tabular}{|c|c|c|}
\hline & $\begin{array}{c}\mathrm{H}_{2} \mathrm{O}(\% \text { peso) } \\
\mathrm{H}_{2} \mathrm{O} \text { (\% weight) }\end{array}$ & $\mathrm{HCl} 20 \%+\mathrm{Na}_{2} \mathrm{CO}_{3} 5 \%$ \\
\hline MA-11 & 80 & 96 \\
\hline $\mathrm{MA}-12$ & 2 & 46 \\
\hline$M A-13$ & --- & 47 \\
\hline MA-15 & 2 & 92 \\
\hline MA-16 & 12 & 99 \\
\hline
\end{tabular}

La primera de ellas es un mortero bastardo, contiene yeso y calcita como ligante y cuarzo como árido. La segunda, y más interna, es casi una lechada de cal con arena cuarzosa como árido y con una relación árido ligante de $1: 10$.

A su vez, la muestra MA-16, tomada bajo la MA-15, contiene yeso ( $12 \%$ ) y calcita ( $85 \%$ ) como componentes más importantes, así como algo de cuarzo.

\section{Sala 3. Dar al Yund}

Los revocos de esta Sala fueron restaurados por Félix Hernández en los años 50 .
The external one contains gypsum and calcite as binding material and quartz as aggregate. The internal is almost a lime grout with some quartz sand as aggregate, and with an aggregate/binder ratio of 1:10.

Sample MA-16 located under MA-15 contains gypsum (12\% wt) and calcite (85\% wt) as main components, as well as some quartz.

\section{Room 3. Dar al Yund}

Rendering mortars in this Room were restored in the 50 's by Felix Hernández. 
Actualmente, sobre los paramentos aparecen restos de mortero de reparación y de revocos originales, en muy mal estado (Ver Figura 2). Se tomaron muestras de ambos materiales; el análisis mineralógico de dicha muestra se presenta en la Tabla V.

La muestra MA-17 corresponde al mortero de reparación y consta de dos capas bien diferenciadas: una, más superficial, de color blanquecino y de unos $3 \mathrm{~mm}$ de espesor, y otra, de color gris, de unos $2-3 \mathrm{~cm}$. de espesor.
Now, on the surface some rests of repairing mortar and original rendering mortars poorly preserved appear (See Figure 2). Samples of both materials were taken; the mineralogical analysis of the sample is shown in Table $V$.

Sample MA-17 corresponds to repairing mortar and has two very well defined layers: a superficial one, of whitish colour and about $3 \mathrm{~mm}$ thick, and another greyish, of about 2-3 cm thick.

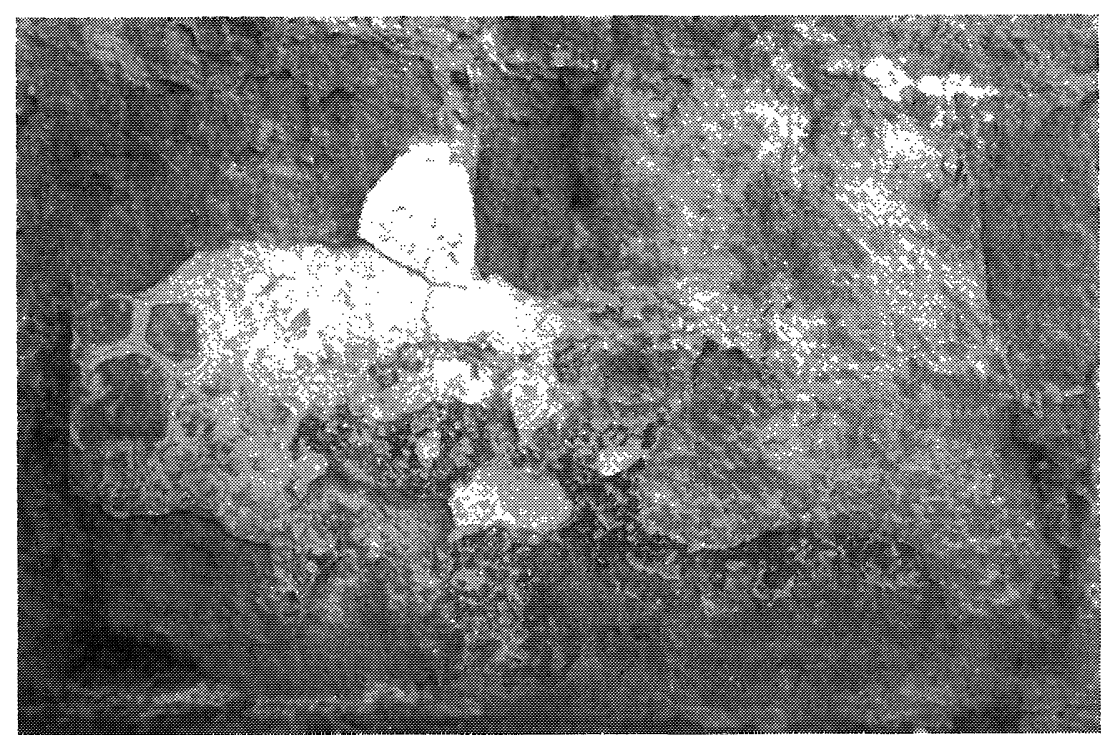

Fig. 2.- Dar al Yund. Restos de morteros originales y de reparación.

Fig. 2.- Iar al Yund. Remainings of original and repairing mortars.

\section{TABLA V (TABLE V)}

Composición mineralógica de las muestras tomadas en el Dar al Yund. Intensidades relativas de las reflexiones características de cada fase

(Mineralogical composition of samples taken in "Dar al Yund". Relative intensity of the diffraction lines characteristic for each phase)

\begin{tabular}{|c|c|c|c|c|c|}
\hline & $\begin{array}{l}\text { CUARZO } \\
(Q U A R T Z) \\
2 \Theta=26,6^{\circ}\end{array}$ & $\begin{array}{c}\text { YESO } \\
(G Y P S U M) \\
2 \Theta=11,7^{\circ}\end{array}$ & $\begin{array}{l}\text { CALCITA } \\
\text { (CALCITE) } \\
2 \Theta=29,4^{\circ}\end{array}$ & $\begin{array}{c}\text { FELDESPATO } \\
\text { (FELDSPAR) } \\
2 \Theta=27,5^{\circ}\end{array}$ & $\begin{array}{c}\text { MICA } \\
\text { (MICA) } \\
2 \Theta=8,9^{\circ}\end{array}$ \\
\hline $\begin{array}{l}\text { MA-17 } \\
\text { GRIS } \\
\text { (GREY) }\end{array}$ & 35 & 9 & 100 & 4 & 2 \\
\hline $\begin{array}{l}\text { MA-17 } \\
\text { BLANCO } \\
\text { (WHITE) }\end{array}$ & 6 & 8 & 100 & --- & $-\cdots$ \\
\hline $\begin{array}{l}\text { MA-18 } \\
\text { SUPERF. } \\
\text { (SURFACE) }\end{array}$ & 7 & 38 & 100 & --- & --- \\
\hline $\begin{array}{c}\text { MA-18 } \\
\text { INTERNO } \\
\text { (INTERNAL) }\end{array}$ & 4 & 100 & 40,5 & --- & --- \\
\hline
\end{tabular}


La primera de ellas es un mortero de cal muy compacto, con escasa cantidad de árido de naturaleza silícea, si bien contiene árido calizo en alguna proporción. Su superficie se encuentra fisurada y presenta colonización biológica por líquenes.

La segunda capa es un mortero de cemento portland. Los áridos son, en este caso, más gruesos $(1,5 \mathrm{~mm}$ de diámetro máximo) y de naturaleza fundamentalmente silícea (arena cuarzosa y feldespatos), así como áridos calizos. Esta segunda capa es más porosa que la primera y la adherencia entre ambas es muy buena.

Ambos morteros contienen pequeñas cantidades de yeso.

La muestra MA-18, es un revoco que superficialmente conserva restos de capa pictórica, y se encuentra en muy mal estado.

Para su examen mineralógico se tomaron dos fracciones, una superficial, conteniendo capa pictórica y otra, más profunda, correspondiente al mortero de base. Ambas fracciones contienen, como compuestos mayoritarios, yeso y calcita, siendo la más superficial, más rica en calcita y la más interna, en yeso. El árido es, fundamentalmente, cerámico.

La superficie de este revoco está muy fisurada, y la capa pictórica no constituye una superficie continua, sino que se encuentra a diferentes niveles, debido a dilataciones o a movimientos del revoco que la sustenta.

Estos revocos están formados por un mortero bastardo, cuyo árido es, fundamentalmente, cerámico.

\section{Patio de los Pilares}

Los estudios, en este caso, se han hecho sobre los restos de recubrimientos policromados existentes en la Alberca situada en la zona central de este Patio. No existe constancia de que dichos revocos hayan sido intervenidos con anterioridad. Se tomaron tres muestras MA-19 del suelo, MA-20 de la pared oeste de la Alberca (Figura 3) y MA-21, pieza encontrada sobre el suelo.

La composición mineralógica de estas muestras se da en la Tabla VI.

La muestra MA-19 es un hormigón muy heterogéneo. En su parte posterior contiene un árido de $3 \mathrm{~cm}$ de longitud, así como áridos más pequeños. $\mathrm{El}$ árido es, en su mayor parte, cerámico. El ligante de este hormigón es cal.
The first one is a very compact lime mortar with little amount of siliceous aggregate and a small proportion of calcareous aggregate. Its surface is cracked and presents a lichened biological colonization.

The second layer is a portland cement mortar. In this case, aggregates are coarser (maximum $1.5 \mathrm{~mm}$ diameter), basically siliceous (quartz sand and feldspar) and calcareous. This second layer is more porous than the first one and the adherence to each other is very good.

Both mortars contain small amounts of gypsum.

Sample MA-18, a rendering mortar still holding visible some rests of the painted surface, is heavily deteriorated.

For its minerological exam two fractions were taken, a superficial one containing depicted coat and a deepest one corresponding to the mortar base. Both fractions contain gypsum and calcite as major components, being the most superficial richer in calcite and the deeper one richer in gypsum. Aggregate is mostly ceramic.

The surface of this rendering mortar is cracked and the depicted coat does not have an even surface due to movements of expansion or shrinking of the material that holds it up.

These rendering mortars are limeigypsum mortars whose aggregate is mostly ceramic.

\section{The Pilares' Patio}

In this instance, the studies have been carried out on remainings of polychrome coatings situated in the reservoir (Alberca) sited in the central area of this patio. There is no evidence these rendering mortars would have ever been repaired before. Three samples were taken, MA-19 from the floor, MA-20 from the west wall of the Alberca (ligure 3) and MA-21 which is a piece found on the floor.

The mineralogical composition of these samples can be found in Table VI.

S'ample MA-19 is made of a very heterogeneous concrete. The back side contains a $3 \mathrm{~cm}$ long aggregate mixed with other smaller aggregates: Aggregate is mostly ceramic. The binding material used in this concrete is lime. 


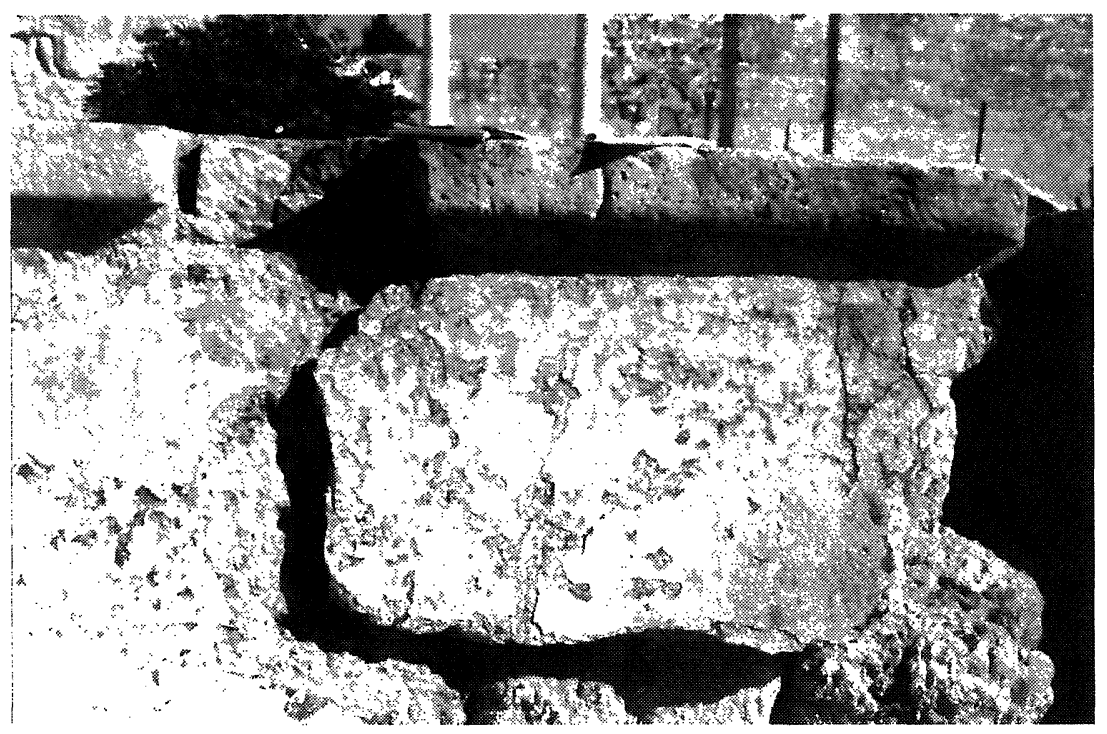

Fig. 3.- Patio de los Pilares. Revoco que recubre la Alberca de este Patio. Morteros de cal con depósitos de carbonato cálcico sobre la superficie pigmentada.

Fig. 3.- Patio de los Pilares. Rendering mortars covering the Alberca in this Patio. Lime mortars with calcium carbonate deposits on the pigmented surface.

\section{TABLA VI (TABLE VI)}

Composición mineralógica de las muestras tomadas en el Patio de los Pilares. Intensidades relativas a las reflexiones de DRX y de las bandas de absorción IR características de las fases (Composition of the samples taken in the Alberca from the Pilares' Patio. Relative intensities of the XRD line, and IR absorption bands characteristic of the phases)

\begin{tabular}{|c|c|c|c|c|}
\hline $\mathbb{R}$ & $\begin{array}{c}\text { CUARZO } \\
\text { (QUARTZ) } \\
2 \Theta=26,7^{\circ}\end{array}$ & $\begin{array}{c}\text { YESO } \\
(G Y P S U M) \\
2 \Theta=11,7^{\circ} \\
\end{array}$ & $\begin{array}{c}\text { CALCITA } \\
\text { (CALCITE) } \\
2 \Theta=29,4^{\circ}\end{array}$ & $\begin{array}{l}\text { FELDESPATO } \\
\text { (FELDSPAR) } \\
2 \Theta=27,5^{\circ} \\
\end{array}$ \\
\hline $\begin{array}{c}\text { MA-19 } \\
\text { POSTERIOR* } \\
\text { (POSTERIOR) * }\end{array}$ & 0 & 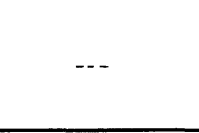 & $x x x$ & --. \\
\hline $\begin{array}{c}\text { MA-20 } \\
\text { DEPOSITO SUPERF. } \\
\text { (SURF. DEPOSIT) }\end{array}$ & -- & 0 & $x x x$ & --- \\
\hline MA-21* & $x$ & -- & $x x x$ & -- \\
\hline \multicolumn{5}{|c|}{$\mathrm{DRX}(X R D)$} \\
\hline MA-20 & 18 & ... & 100 & 2 \\
\hline
\end{tabular}

* Muestras enriquecidas en ligantes: $x x x$ muy abundante, $x x$ abundante, $x$ poco, 0 trazas

* Samples enriched with binders: $x x x$ very abundant, $x x$ less abundant, $x$ scarce, 0 small quantities

La muestra MA-20, tomada de la pared oeste de la Alberca, está constituida por un mortero de cal con árido silíceo y cerámico, de tamaño inferior a $6 \mathrm{~mm}$. Sobre el muro donde se tomó la muestra se pueden observar morteros con áridos cerámicos, de tamaño muy superior (2 y $3 \mathrm{~cm}$ ). Esta muestra contiene un depósito superficial
Sample MA-20, taken from the west wall of the Alberca is made of lime/siliceous and ceramic aggregate with diameter smaller than $6 \mathrm{~mm}$. On this wall other mortars whose aggregate is much bigger in size $(2$ to $3 \mathrm{~cm}$ ) can be observed. This sample contains a superficial layer of $\mathrm{CaCO}_{3}$ resulting from the 
constituido por $\mathrm{CaCO}_{3}$, que procede de la disolución por el agua del carbonato del mortero base y la posterior precipitación en la superficie al evaporarse el agua.

La muestra MA-21 tiene la peculiaridad de contener dos capas pictóricas.La base de la muestra es un mortero muy basto, con árido de diámetro máximo de algo más de $1 \mathrm{~cm}$. El mortero es de cal y los áridos,

fundamentalmente, cerámicos y arenas cuarzosas.

\section{Vivienda del Servicio}

Esta Sala, situada al fondo, en el Patio del horno, no ha sido reparada ni restaurada, por lo que los restos son originales. En esta Sala quedan restos de revocos policromados, tanto en el suelo como en alguna pared.

En ella se han tomado tres muestras, MA-22, MA-23 y MA-24. Las dos primeras corresponden, respectivamente, a un revoco de suelo con restos de policromía y un hormigón base de ese revoco. La muestra MA-24, que se toma en la pared, tiene restos de policromía y tiene gran abundancia de crecimiento biológico.

En la Tabla VII se da la composición mineralógica de estas muestras, obtenida por DRX.

El ligante de las tres muestras extraídas es cal y no se ven trazas de yeso.

La muestra MA-22, es un mortero de cal con áridos de hasta $1 \mathrm{~cm}$ de longitud máxima y bastante compacto, presenta restos de capa pictórica muy bien adheridas al substrato, allí donde todavía existe.

La muestra MA-23, base de la MA-22, es un hormigón de árido muy grueso, de hasta $3 \mathrm{~cm}$ de longitud y constituido, fundamentalmente, por trozos de material cerámico. El ligante de este hormigón es, como ya se ha mencionado, cal dissolution of the mortar base caused by water, and the further precipitation in the surface as water evaporates.

Sample MA-21 is a peculiar one since it contains two depicted layers. The base is made of coarse mortar with an aggregate slightly larger than $1 \mathrm{~cm}$. This mortar is made of lime, and aggregates are ceramic and quartz sand.

\section{Servant's Room}

This Room, located at the bottom of the "Patio del horno", has not been either repaired or restored, consequently everything is original. In this Room remainings of polychromed rendering mortars were found on the floor and in some of the walls.

Three samples were taken there, $M A-22, M A-23$ and $M A-24$. The first and second were taken off the rendering mortar of the floor. They belong, respectively, to a piece of the floor with some rests of polychromy. and to a piece of the concrete supporting that one. Sample MA-24, taken from the wall, has also some rests of polychromy; it has abundant biological growth.

In Table VII the mineralogical composition obtained through XRD of the three samples is given.

The binding material of the three samples is lime, and no traces of gypsum can be seen.

Sample MA-22, a very cohesive lime mortar with aggregates up to $1 \mathrm{~cm}$ long, shows a depicted coat pretty well stuck to the substrate, where coat still exists.

Sample MA-23 -base of MA-22- is of concrete with a very coarse aggregate up to $3 \mathrm{~cm}$ long, mainly containing ceramic chunk. The binder of this concrete is lime.

\section{TABLA VII (TABLE VII)}

Composición mineralógica de las tres muestras tomadas en la Vivienda de Servicio. Intensidades relativas $(\%)$, de las reflexiones DRX características de las fases (Mineralogical composition of the three samples taken Servant's Room. Relative intensities $(\%)$ of the XDR lines characteristic of the phases)

\begin{tabular}{||c|c|c|c|c||}
\hline $\begin{array}{c}\text { MUESTRA } \\
\text { (SAMPLE) }\end{array}$ & $\begin{array}{c}\text { CUARZO } \\
\text { (QUARTZ) } \\
2 \Theta=26,7^{\circ}\end{array}$ & $\begin{array}{c}\text { YESO } \\
\text { (GYPSUM) } \\
2 \Theta=11,7^{\circ}\end{array}$ & $\begin{array}{c}\text { CALCITA } \\
\text { (CALCITE) } \\
2 \Theta=29,4^{\circ}\end{array}$ & $\begin{array}{c}\text { FELDESPATO } \\
\text { (FELDSPAR) } \\
2 \Theta=27,5^{\circ}\end{array}$ \\
\hline MA-22 & 23 & -- & 100 & 1,5 \\
\hline MA-23 & 46 & --- & 100 & 6 \\
\hline MA-24 & 13 & --- & 100 & 1 \\
\hline
\end{tabular}


Finalmente, la muestra MA-24 es un mortero con árido también cerámico en su mayor parte, de diámetro inferior a $3 \mathrm{~mm}$ y cuyo ligante es cal.

\section{DISCUSIÓN}

Al examinar los resultados se deduce que los morteros utilizados en el recubrimiento de paramentos y suelos son de distinta naturaleza, en función de que su situación en el edificio fuera interior o exterior.

En zonas que originalmente eran interiores, los paramentos pétreos se recubrían con revocos de cal o bastardos pobres en yeso, pero el acabado final se hacía con mortero de yeso o bastardo.

Así, pues, en la Sala 1 de la vivienda de Yafar, los paramentos pétreos tienen algunas zonas cubiertas con restos de morteros de yeso (en la zona superior) de cal (en la zona intermedia) ó bastardos (en la zona baja) (Figura 4). Sobre estos morteros aparecen otros de yeso ó bastardos en las dos zonas inferiores. La policromía está sustentada por morteros bastardos.
Finally, sample MA-24 is also a mortar prepared mostly with ceramic aggregate, smaller than $3 \mathrm{~mm}$, and lime as binder.

\section{DISCUSSION}

After thorough examination of the results, the sum up is that mortars used for covering wall surfaces and floors have a different composition as a function of their situation -indoors or outdoors- in the building.

In originally indoors zones, stone walls were covered with lime rendering mortars or with gypsum-lime mixture, poor in gypsum, but the final coat was made of gypsum or mixed lime-gypsum mortars.

So, in Room 1 of Yafar's house, stone walls have some areas covered with remainings of gypsum mortar (upper level), of lime (intermediate level) or mixed lime-gypsum (lower level) (Figure 4). Over these mortars, other gypsum or mixed lime-gypsum mortars appear in the lower level. Polychromy is held up by mixed mortars.

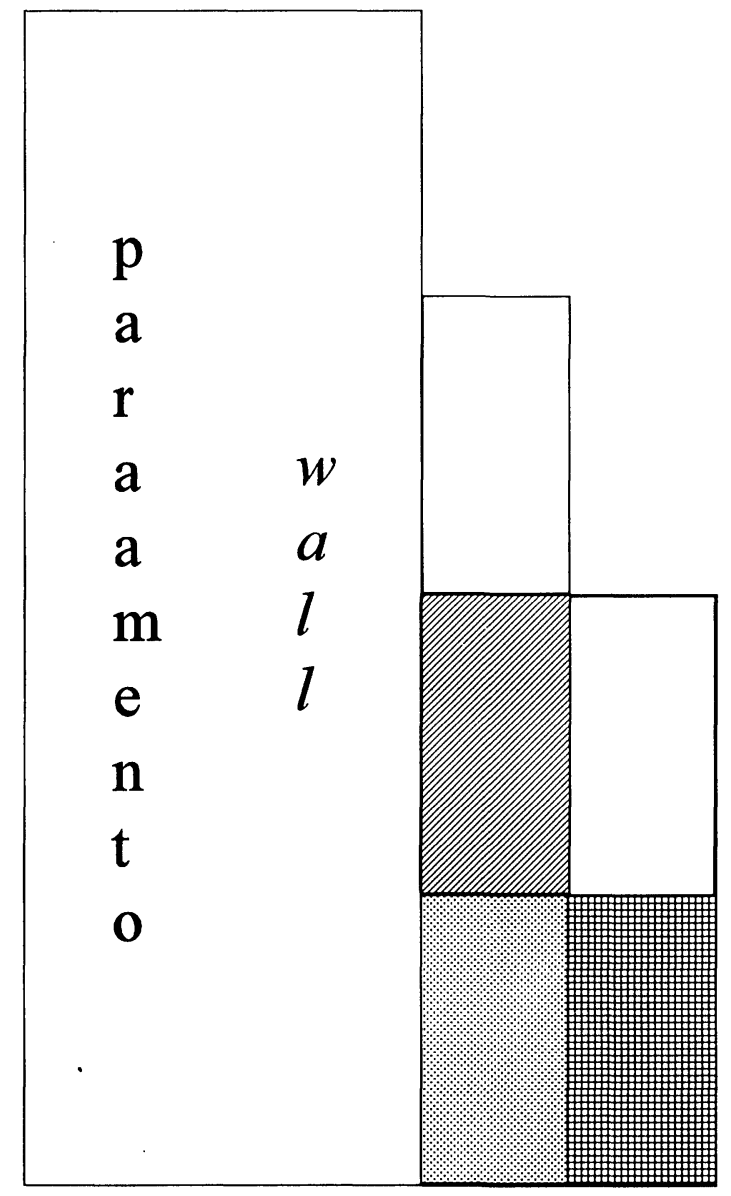

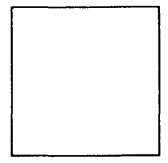

Yeso / Gypsum

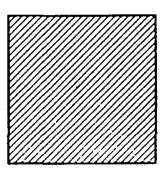

Cal / Lime

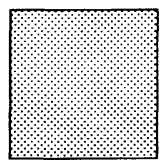

Bastardo, pobre en yeso

Mixed, poor in gypsum

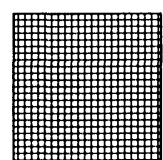

Bastardo / Mixed 
En la Sala 2 de la vivienda de Yafar, los paramentos pétreos tienen algunas zonas cubiertas con restos de morteros de cal (zona superior) ó bastardos, con muy poco yeso (zona inferior).

Sobre estos morteros, aparecen otros de yeso en las zonas más altas y bastardos en las zonas inferiores (Figura 5).

En las reparaciones y sellado de bordes de los morteros de ambas Salas se utilizaron morteros de cal, que se encuentran aceptablemente adheridos a los revocos y que, hasta cierto punto, les han protegido de la lluvia que pudiese percolar desde la parte superior de los mismos, si ésta se encontrase descarnada.

La solubilidad del yeso en agua $(2,4 \mathrm{~g} / 1)$ es suficientemente alta como para que los revocos sufran procesos de disolución y la consiguiente disgregación a lo largo del tiempo (3). Revocos compactos, poco porosos y con superficies externas pulidas, de modo que su rugosidad sea menor y la superficie de exposición al agente agresivo (agua) inferior, podrían resistir, hasta cierto punto, la acción de la lluvia.
In Room 2 of Yafar's house, stone walls are partially covered with rests of lime mortars (upper level) or mixed with little gypsum mortars (lower level).

Over these mortars, others of gypsum appear in upper levels or mixed in lower levels (Figure 5).

In both Rooms, the repair and sealing the edges was made with lime mortars. They still keep good adherence condition for protection from rain that could percolate from the top if this one would have been worn away.

The solubility of the gypsum in water $(2.4 \mathrm{~g} / \mathrm{l})$ is high enough as to make rendering mortars to undergo dissolution processes with the subsequent disintegration as time goes by (3). Compact rendering mortars, scarcely porous and having polished external faces in such a way that roughness would be lesser and the surface exposed to the aggressive agent (water) smaller, would manage to resist, to some extent, the action of the rain.

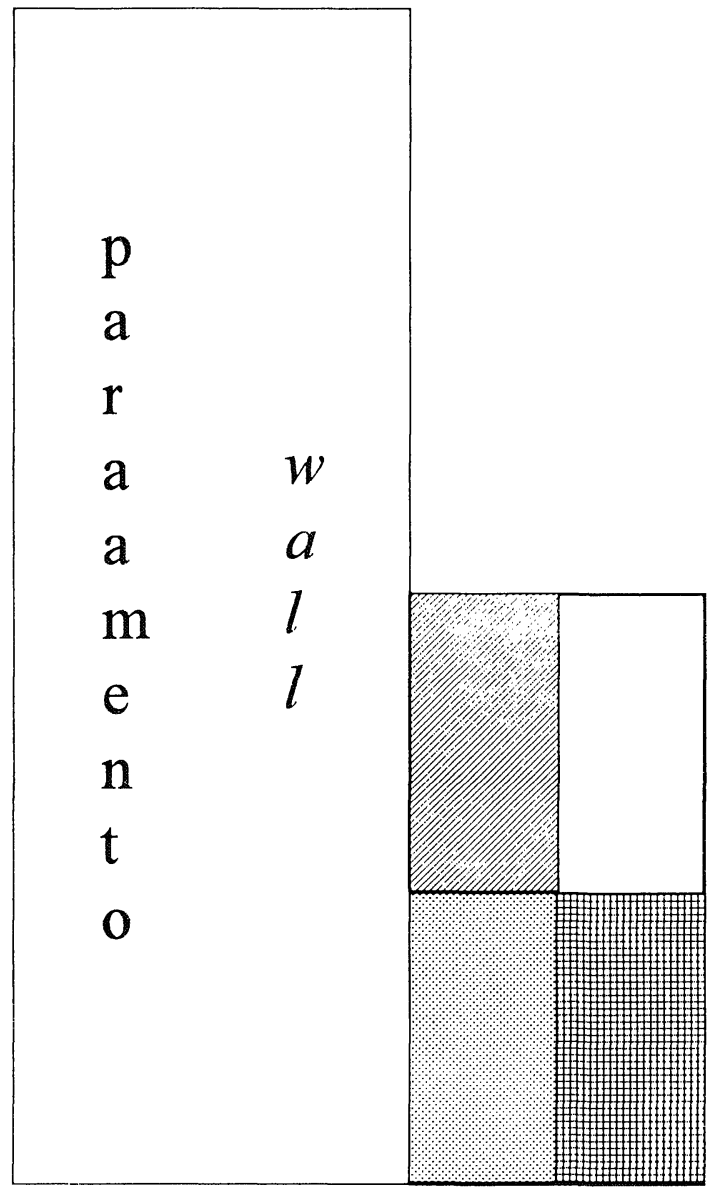

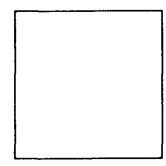

Yeso / Gypsum

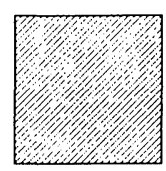

Cal / Lime

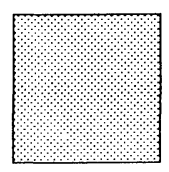

Bastardo, pobre en yeso

Mixed, poor in gypsum

Fig. 5.- Capas de mortero sobre los paramentos de la Sala 2.

Fig. 5.-Mortar coats on the walls of Room 2.

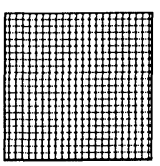

\section{Bastardo / Mixed}


Los revocos estudiados están situados sobre muros cuya parte superior carece de protección frente a la lluvia, de modo que se puedan empapar y el agua percolar hasta las zonas bajas (estucadas), donde evaporaría. Además, tales revocos no son muy compactos, su superficie está bastante alterada $\mathrm{y}$, si bien están protegidos en su borde, reciben el ataque del agua de lluvia que circula a través de ellos desde los muros y la que directamente les puede alcanzar. Su conservación, en estas condiciones, no parece fácil.

Los morteros de reparación extraídos en la Sala 3, Dar al Yund, están aplicados en capas sucesivas. La capa situada sobre el muro es un mortero de cemento portland compacto y la de acabado, más porosa que la anterior, es un mortero de cal. La adherencia entre ambas capas es buena.

Los morteros originales de esta sala contienen yeso en cantidad importante y su estado de conservación es muy deficiente, por las mismas razones ya argumentadas previamente. No parece que los morteros de reparación aplicados hayan protegido a los originales del deterioro provocado por la intemperie.

En zonas que siempre han estado a la intemperie o en contacto con agua (suelos, albercas, etc.) los morteros son de cal. El estado de conservación de estos morteros es mejor que el mostrado por los morteros de yeso o de cal y yeso, toda vez que su cohesión interna es superior y la solubilidad del $\mathrm{CaCO}_{3}(0,014 \mathrm{~g} / \mathrm{l})$ es muy inferior a la del yeso, por lo que resisten mejor la intemperie. A este mejor comportamiento contribuye el árido cerámico que contienen, ya que probablemente se ha producido una reacción puzolánica de dicho árido con la cal del mortero, lo que ha incrementado la cohesión interna y durabilidad de los morteros. Sin embargo, dichos morteros presentan una fuerte colonización biológica, con importantes erosiones superficiales, cuando están en zonas húmedas.

\section{CONCLUSIONES}

$\left.1^{a}\right)$ Los revocos están formados por tres clase de morteros, atendiendo a la composición de su ligante: de cal, de yeso y bastardos.

$\left.2^{a}\right)$ El árido utilizado más frecuentemente en dichos morteros es el cerámico, sin excluir por ello que se hayan usado, además, áridos silíceos y algunos calizos.

$3^{a}$ ) En zonas que originalmente eran interiores, los paramentos pétreos se recubrían con revocos de cal o bastardos pobres en yeso, pero el acabado final se hacía con mortero de yeso o bastardo.
Rendering mortars studied stick to walls whose top lacks of protection against rain in such a way that it can percolate from top to bottom place covered with stuccos where evaporation would take place.

Moreover, these mortars are not very compact, their surface is quite altered and even though their edges are protected they still get rain water directly or filtered through down the walls. These conditions does not seem an easy way for preservation.

Repairing mortars selected at Room 3, Dar al Yund, have been laid in two successive coats. The coat sticking to the wall is a compact portland cement mortar and the finishing coat is a more porous lime mortar. The adherence to each other is good.

The original mortars of this room contain an important amount of gypsum and they are in a very deficient preservation condition because of the previous facts stated. It does not seem that repairing mortars would have protect the original ones from open air deterioration.

In the zones that have always been in the open or in contact with water (reservoirs, etc.) mortars are of lime. The conservation of these mortars is better than those of gypsum or lime/gypsum mortars since their internal cohesion is higher, and the $\mathrm{CaCO}_{3}$ solubility $(0.014 \mathrm{~g} / \mathrm{l})$ is lower than this of gypsum, reason why they are more resistant to open air. The possibility of a pozzolanic reaction between the ceramic aggregates and lime can be contributing to the better behaviour (more internal cohesion and durability) of these mortars. However, these mortars show a strong biological colonization, with important superficial erosion when sitting in humid areas.

\section{CONCLUSIONS}

$\left.1^{a}\right)$ Rendering mortars are made of three different types depending on the composition of their binder: lime, gypsum or mixed lime-gypsum.

$\left.2^{a}\right)$ The most frecuently used aggregate in such mortars is ceramic and some silicious and calcareous ones.

$\left.3^{a}\right)$ Originally indoor zones, have stone walls covered with mortar either of lime or hybrid lime/gypsum with poor in gypsum content, but the final coat was made of gypsum or hybrid. 
$\left.4^{a}\right)$ En zonas que siempre han estado a la intemperie o en contacto con agua (suelos, albercas etc.), los morteros aplicados sobre las superficies pétreas eran de cal.

$\left.5^{a}\right)$ La principal causa de deterioro en los revocos de yeso o bastardos es la solubilización por el agua.

$6^{a}$ ) Los revocos de cal sufren también solubilizaciones en agua de su ligante, y presentan, en ocasiones, depósitos de calcita recristalizada sobre su superficie, pero su principal causa de deterioro es la colonización biológica.

$7^{a}$ ) Los morteros de reparación que se han utilizado son de cal, a excepción del utilizado en la sala 3, que es de cemento portland.

$\left.8^{a}\right)$ Los morteros con los que se han sellado los bordes descarnados de los revocos no han contribuido a su deterioro, pero tampoco lo han podido evitar, puesto que el problema no está sólo en el borde, sino en el agua que circula dentro del propio muro.

\section{AGRADECIMIENTOS}

Los autores agradecen a la Consejería de Cultura de la Junta de Andalucía la subvención concedida a este trabajo, a la Dirección del Conjunto Arqueológico las facilidades dadas para su ejecución y, en especial, a Dña. Elisa Pinilla, por su apoyo y colaboración. $\left.4^{a}\right)$ Outdoor areas that have always been in contact with water (floors, ponds, etc.), have lime mortars covering stone surfaces.

$\left.5^{a}\right)$ The main cause for deterioration in gypsum or gypsum/lime mortars is the solubilization by water.

$\left.6^{a}\right)$ Lime mortars also endure solubilizations by water content in binder, and they show deposits of crystallized calcite on their surface, although the biological colonization is the main cause for deterioration.

$\left.7^{a}\right)$ Repairing mortars are made of lime except the one utilized in Room 3 which is of portland cement.

$\left.8^{a}\right)$ Mortars applied for repair on the stripped off edges of rendering mortars did not contribute to deterioration but they did not prevent it either, since the problem should not only be focussed on the edges but also in the water that flows through the inner pores of the wall.

\section{ACKNOWLEDGEMENTS}

Authors thank the Consejeria de Cultura de la Junta de Andalucia for the financial aid granted, the Board of Directors of the Conjunto Arqueologico for the facilities entrusted, and specially to Ms. Elisa Pinilla for her support and collaboration in the achievement of this work.

\section{BIBLIOGRAFÍA}

(1) CASTEJÓN, R.: “Medina Azahara” Editorial Everest, 1976.

(2) SAIZ JIMÉNEZ, C., HOYOS, M. y BLANCO-VARELA, M.T. et al.: "Estudio de los procesos de alteración de los materiales pétreos y estucos de Madinat al Zahra". Estudio diagnosis de los Conjuntos y yacimientos arqueológicos de la Comunidad Autónoma Andaluza en su contexto geomorfológico, biológico y clímatico. Consejería de Cultura, Junta de Andalucía (1995).

(3) FURLAN, V.: "Causes, mechanisms and measurement of damage to mortars, bricks and renderings". Science, Technology and European Cultural Heritage. Ed. N.S. Baer et al. pp149-159 Bolonia (Italia), 1989. 